\title{
UTILIZAREA ENGLEZISMELOR ÎN LIMBA ROMÂNĂ ÎN CONTEXTE ADECVATE
}

\author{
Livia CARUNTU-CARAMAN \\ Institutul de Filologie Română „Bogdan Petriceicu-Hasdeu”, Chișinău
}

Rezumat. Actualmente, limba engleză oferă un inedit prototip de socializare internațională, delegându-și mijloace de exprimare în cele mai multe limbi ale lumii. Prin comunicare mediatică, deschisă tuturor înnoirilor lexicale, cuvinte de origine engleză pătrund și în limba română, căutându-și locul adecvat în diferite contexte. Englezismele sunt o realitate, o atestare actuală a evoluţiei limbii noastre. Ele își demonstrează funcționalitatea în comunicare, iar reiterativitatea în circuit le marchează însăşsi utilitatea lor.

În lucrarea de față, urmărim încadrarea englezismelor din varii domenii de activitate în diferite pasaje. Cercetăm relevanța lor în exemple concrete, gradul de necesitate, de adaptare, de corectitudine, dar și frecvența utilizării acestora în massmedia. Astfel, vom constata interactivitatea dintre nivelul dezvoltării limbii române și utilizatorii ei care contribuie la îmbogățirea și modernizarea vocabularului nostru, pentru a ne realiza pe scară internațională.

Cuvinte-cheie: Englezisme, normă, funcționalitate, utilizare corectă, context, massmedia, modernizarea lexicului.

Abstract. Currently, English offers a novel prototype of international socialization, delegating its means of expression in most languages of the world. Through media communication, opened to all lexical renewals, English words also penetrate the Romanian language, looking for an adequate place in different contexts. The Anglicisms are a reality, a current attestation of our language evolution. They demonstrate their functionality in communication, and the repetitiveness in the circuit marks their usefulness.

In this paper, we aim the enclosing of Anglicisms from various fields of activity in different passages. We research their relevance in concrete examples, the degree of necessity, adaptation, correctness, but also the frequency of their use in the mass media. Thus, we will establish the interactivity between the level of Romanian language development and its users that contribute to the enrichment and modernization of our vocabulary, in order to achieve ourselves on an international scale.

Keywords: Anglicisms, norm, functionality, correct use, context, mass media, lexicon modernization. 
Comunicarea mediatică este deschisă tuturor înnoirilor lexicale. Lucrarea de faţă este justificată de sporirea semnificativă a ponderii influenţei engleze în terminologia mass-media în contextul general al pătrunderii englezismelor în limba română, cuprinzând toate sferele de activitate publică.

Mass-media, fiind principala furnizoare de englezisme, „construieşte o realitate secundă, bazându-se pe informaţii, relatări şi interpretări pe care ea le selectează (prin funcţia de agenda-setting), le ordonează (în raport de priorităţi), le prelucrează şi le răspândește în rândul publicului, apelând la o anumită terminologie (care ,etichetează” şi valorizează prin utilizarea unor stereotipuri politice, culturale, religioase menite să asigure integrarea şi omogenizarea socială). În raport cu publicul, mass-media vizează patru obiective: sensibilizarea şi informarea asupra unui anumit subiect, formarea unor atitudini faţă de acesta şi, în sfârşit, influenţarea comportamentului într-o anumită direcţie (,orientarea" opiniei publice)" (Stoichiţoiu-Ichim, 2003).

Deoarece presa reprezintă ,și un important factor cultural-educativ", ea poate contribui ,,pe de o parte la educarea lingvistică a publicului, iar pe de altă parte la îmbogățirea, diversificarea și internaționalizarea lexicului limbii literare" (Stoichițoiu-Ichim, 2007, p. 85). Prin „larga sa audiență, prin autoritatea cuvântului tipărit sau rostit la microfon, presa a avut și continuă să aibă un rol însemnat în difuzarea și impunerea inovațiilor lingvistice și, în primul rând, a cuvintelor împrumutate pe cale livrescă din limbi străine" (Stoichițoiu-Ichim, 1996, p. 37).

În această ordine de idei, aportul mass-mediei, în general, iar în cazul investigației noastre - din spațiul românesc, într-un concret interval de timp, este indiscutabil. Publicațiile periodice devin primul mijloc savant de mediatizare a englezismelor care-și fac loc în limba română pe cale orală, dar și o credibilă sursă din care publicul larg de cititori ia pentru întâia oară cunoștinţă de multe cuvinte străine, văzându-le tipărite, exprimând ceva - deci viabile, pe care își vor permite mai lesne să le utilizeze apoi și în propriul vocabular. În așa fel, valorile semantice ale englezismelor sunt interceptate şi redate mai calitativ în comunicare; totodată se caută colectiv, se probează de mai multe ori în diferite variante și se fixează formulele adecvate. Numai uzul le confirmă ponderea semnificativă, corectitudinea și utilitatea lor; ceea ce intră și în competența ziariștilor - să dea posibilitate neologismelor să-și manifeste dreptul funcțional.

Astfel, depistăm că modul fresh al noii exprimări cuprinde toate sferele de activitate a societății noastre de azi. Iar mass-media, mai cu seamă, urmărește și ghidează, acumulează și prelucrează materialul brut, apoi îl redă publicului utilizator și cititor deja probat.

Viabilitatea sistemului lexical al limbii și caracterul lui deschis a fost relevat de lingvistul suedez Alf Lombard: „Când româna importă un cuvânt străin, ea 
păstrează foarte adesea cuvântul anterior care servește pentru a exprima același lucru. Numărul cuvintelor întrebuințate de români nu încetează să crească. Limba lor a devenit o limbă mai mult decât bogată. Importul aproape nelimitat de cuvinte noi, cadrul uimitor de extensibil al vocabularului, felul în care cuvintele trăiesc împreună în interiorul acestui cadru, concurența dintre cuvintele care aparţin straturilor diferite, diferenţierea semantică sau geografică a sinonimelor - toate aceste probleme lexicologice constituie un întreg pe care nicio altă limbă nu-l oferă mai bine studiului” (apud: M. Graur-Vasilache, p. 214).

Așa e util cuvântul, spus și pus la locul și la timpul potrivit. Cu cât sensul lui este sesizat de mai mulți vorbitori, cu atât mai lesne se produce comunicarea în interiorul spațiului de consumare. Iar cu cât termenii se internaționalizează, devin un bun comun de exprimare și pentru vorbitorii altor limbi. Întrucât engleza răspândește noțiunile sale neologice în diferite limbi, acestea le adoptă și le adaptează după legile locului, apoi, prin vocabularul internaționalizat, îl întorc în comunicarea internațională. La o necesitate, cunoscând originile, un anumit procentaj de cuvinte dintr-un mesaj ar putea fi înțeles de vorbitori de altă limbă: polonez, luxemburghez, portughez. În așa mod, limba engleză conturează un nou prototip de socializare internațională (Caruntu-Caraman, 2017, p. 98).

În acest scop și limba română apelează la englezisme - să fie înţeleasă și accesibilă în anturajul universal. Iată de ce zicem că englezismele sunt și ele o marcă de demonstrare a implicării noastre în apropierea de Europa. Iar cu cât un domeniu sau altul de activitate, prin care ne edificăm viitorul, este pătruns mai profund de progresul modern, el nu poate să nu se internaţionalizeze și să nu se modernizeze măcar prin vocabular, la început. Pe urmă se vor impune integral: și tehnic, și relațional, și mental.

În etapa actuală, constatăm că în limba română a pătruns un număr considerabil de englezisme, în special, prin intermediul mass-mediei (presei scrise și audiovizuale). Acestea își caută un loc cât mai potrivit în limbă, adaptându-se și adecvându-și bogate valori semnificative. Ziariștii le culeg din vorbire, din alte surse, le aştern în articole, schiţe, reportaje, corespondenţe, convinşi de beneficiul ce-l aduc limbii, apoi le întorc în comunicare publicului cititor care le redescoperă, le reconsumă, le reevaluează şi le hotărăsc destinul lor în continuare. Cercetătorii le ţin sub observaţie, le analizează şi le apreciază rostul, totodată urmărind funcționalitatea și utilizarea corespunzătoare în contexte: cuvântul potrivit să-și aibă locul potrivit.

Într-un studiu special dedicat problemei în discuție, se referă la situația dată și cercetătoarea I. Condrea care subliniază că „limba engleză este o sursă foarte activă de îmbogăţire a vocabularului și, practic, orice persoană care, cel puțin, citește ziare sau ascultă radioul trebuie să cunoască un anumit număr de englezisme, 
pentru a înțelege corect mesajul difuzat. Unele cuvinte împrumutate au făcut deja o carieră atât de fulgerătoare, încât avem impresia că fără ele nici nu ne-am putea înțelege" (2002, p. 10). În așa mod, englezismele își demonstrează funcționalitatea în comunicare, iar reiterativitatea în circuit le marchează însăşi utilitatea lor.

„Ziariștii apelează la utilizarea, în același context, a termenilor de origine străină alături de cuvintele din limba română cu scopul de a evita monotonia lexicală, pentru respectarea exactităţii și a clarităţii exprimării, pentru o transpunere cât mai fidelă a realităților descrise. Toate aceste modalități de utilizare a vocabularului constituie o particularitate distinctă a stilului publicistic" (Graur Vasilache, 2003, p. 219).

Totodată, utilizarea englezismelor reiese din necesitatea de a crea originalitate stilistică, dar are şi aspecte negative, precum „,veleitarismul intelectual, insuficienta cunoaştere a resurselor limbii materne, comoditatea sau graba, care nu întotdeauna permite alegerea unui echivalent potrivit contextului” (Stoichițoiu-Ichim, 1996, p. 40).

Destul de bine a ilustrat și George Pruteanu această situație, comentând într-o postare pe site-ul personal „Agramatica micului (dar răului!) ecran”, impactul massmediei asupra societății și limbii în general. „Stil de viaţă, ţinută, luk, îmbrăcăminte, atitudini, mişcări, gesturi, poziţii, intonaţii, accentuări, vocabular, topică - toate trec iute şi eficace de pe micul ecran pe marea şi noroioasa scenă a vieţii” (Pruteanu).

Aspectul adaptării împrumuturilor în limba română ,este un proces de oarecare durată, cu perioade de fluctuații, până când cuvântul își găsește forma potrivită care să-l fixeze în sistemul existent. Durata perioadei de adaptare depinde mai ales de frecvența în circulație a cuvântului” (Iordan, 1978, p. 314-315).

În acelaşi context, abordând englezismele din perspectiva normei lingvistice, A. Stoichițoiu-Ichim evidențiază ,aspecte complexe și, uneori, contradictorii, precum numeroase fluctuații, explicabile prin cauze obiective (caracterul recent al împrumuturilor, circulație limitată, dificultăți de asimilare datorate diferențelor dintre sistemele lingvistice ale românei și englezei) și subiective (gradul de stăpânire a limbii engleze, comoditatea, mimetismul și snobismul lingvistic)" (2007, p. 96).

Deşi aceste probleme persistă, ele nu sunt un obstacol în calea apariţiei englezismelor. Acest fenomen este de lungă durată şi doar utilizarea frecventă a termenilor îi va încetăţeni în limbă. Totuşi, pentru a evita unele abateri de la normă şi a folosi corect formele cuvintelor este necesar ca utilizatorii englezismelor să se cultive permanent, să consulte gramatică, surse ortografice şi ortoepice şi dicţionare de specialitate.

Familiarizarea, cunoașterea cuvintelor este în strânsă relaţie cu frecvența acestora în mass-media, chiar și popularitatea termenilor depinde de gradul 
de apariție în ziare, reviste, la TV, radio, pe stradă. Astfel, în urma identificării termenilor în pasaje concrete, cuvintele podcast, fake-news, contactless, influencer, vlogger, fastfood, webinar, trending, cash-back, lockdown, cookie, teaser, online, briefing, bullying, challenge, task, deadline sunt cele mai frecvent utilizate.

Prin urmare, în mass-media utilizatorii folosesc în mare metodele de plată contactless. Școala on-line a devenit o realitate acum și în Moldova. Tot în mediul online sunt răspândite fake-news-urile și se organizează webinare gratuite pe teme diverse. Chiar și cursurile de instruire online devin tot mai populare. Acceptăm task-uri, respectăm deadline-uri. Bullying-ul este o traumă și poate fi oprit doar printr-un efort colectiv. Informația se anunță la briefinguri. Consumul de mâncare tip fastfood este un subiect des adus în discuție. Site-urile folosesc cookie-uri pentru a îmbunătăți experiența utilizatorilor. Interpreții fac tot mai multe life-uri și își publică teaserele noilor videoclipuri, care ajung în final pe locuri de top în trendinguri. În contextul pandemiei, autorităţile instituie lockdown. Burnout-ul ne-a afectat într-un procent extraordinar după un an de criză. Adesea, influencerii îşsi ghidează comunitatea online către produse şi servicii pentru care fac publicitate. Iar vloggerii recurg de multe ori la challenge-uri amuzante și distractive.

Unele englezisme pătrund, de la început, cu o mică familie sau și-o formează/ complinește pe parcurs cu împrumuturi tot de la sursă. Așadar, mult cunoscutul podcast circulă cu sensurile: 1) Conținut multimedia (muzică, video, emisiune $\mathrm{TV}$, radio etc.) distribuit pe internet. $N$-am ascultat niciodată un podcast. 2) Aplicație care permite preluarea de pe internet a acestor conținuturi. Podcastul funcționează cu ajutorul unui software specializat. Concomitent cu acesta pătrunde și podcasting (metodă de distribuție și amenajare pe internet a fișierelor în format multimedia), de la care se formează substantivul masculin, mai nou, și feminin podcaster/ podcasteriță (autor/ autoare de podcast). Mai jos identificăm aceste cuvinte în contexte:

- Podcast-ul este un fel de emisiune radio pe o temă anume.

- Podcastul este în format audio și este ușor de accesat.

- Ne place să ascultăm muzică sau podcast-uri aproape peste tot.

- Cele mai multe podcasturi sunt gratuite.

- Aproape $25 \%$ dintre consumatorii de peste 55 de ani ascultă podcast-uri lunar.

- Conform statisticilor mondiale, podcast-urile prind o anvergură demnă de invidiat în rândurile consumatorilor de conținut digital.

- Industria de podcasting a început ca o activitate pentru amatori.

- Site-urile de podcasting pot oferi fișierele spre descărcare și ascultare off-line sau pentru redare directă on-line.

- Comunităţile folosesc podcasturi colaborative pentru a sprijini podcasting-ul mai multor participanți. 
- Aceste emisiuni live reunesc publicul, gazdele și specialiștii în marketing, ajutând podcasterii să creeze conexiuni.

- Podcasterii pot să se înscrie pe https://googlecp.prx.org/ pentru sfaturi, cursuri video și cursuri de la distanță despre podcasting, toate gratuite.

- Podcasterii spun că platforma le-a eșuat într-o varietate de moduri.

- Podcastul se poate difuza atât live, pe canalele alese de podcaster, dar poate fi şi înregistrat.

- Compania Apple a organizat o întâlnire secretă cu cei mai influenţi podcasteri ai platformei iTunes.

Aceste cuvinte apar și în îmbinări (platformă de podcast, episod de podcast, producător de podcast, ascultător de podcast, abonaţii podcast-ului, actualizarea podcast-ului, administrarea podcast-urilor, podcast-uri contemporane, podcast-uri românești, portal de podcast-uri, podcast-uri Google, podcast-uri live; expert în podcasting, instructor de podcasting, industrie de podcasting, școală de podcasting, site-uri de podcasting, abilități de podcasting; comunitate de podcasteri.

O altă familie identificată este merchandiser, care se pronunță mercendáizăr - agent comercial care promovează produsele noi și serviciile unei firme, distribuind material publicitar (afișe, pliante, etichete) în acest scop (Merchandiserul poate fi cheia creşterii vânzărilor pe timp de criză) și merchandising, pronunțat mercendáizing - totalitatea metodelor, practicilor și operațiunilor de prezentare și promovare a produselor în rândul consumatorilor, cu scopul optimizării vânzărilor (Unul din elementele foarte importante ale merchandisingului este comunicarea).

- Jobul de merchandiser nu implică experiență de muncă, însă necesită abilități creative, analitice.

- Programul de lucru al unui merchandiser este de obicei de opt ore, de luni până vineri.

- Salariul unui merchandiser diferă foarte mult în funcție de experiența candidatului şi de tipul magazinului.

- Merchandiserii planifică și gestionează game de produse, inventar, afișaje și promoții.

- Merchandising-ul serveşte pentru a vinde mai mult şi mai bine în mod direct.

- Merchandising-ul susţine creşterea vânzărilor.

- Merchandising-ul înseamnă produsul potrivit, la locul potrivit, momentul potrivit, în cantităţi potrivite şi la preţul potrivit.

- În cazul în care standardele de merchandising sunt încălcate în zona de vânzare, compania obține mai puțin profit.

- Merchandising-ul a luat naștere odata cu apariţia hypermarketurilor. 
- Politica de promovare și implicit merchandising-ul produselor medicamentoase se supun anumitor reguli.

- Merchandisingul este extrem de important pentru orice plan de marketing și pentru orice magazin, fie el mic sau mare.

Îmbinările în care apar sunt următoarele: atribuțiile merchandiser-ului, obiectivele merchandiser-ului, echipe de merchandiseri; tehnici de merchandising, costuri de merchandising, conceptul de merchandising, metode de merchandising, merchandising operațional, principiile merchandising-ului, beneficiile merchandising-ului, importanța merchandisingului.

Tot cu o mică familie au pătruns și englezismele advertising, advertiser; blog, blogger, blogging; brand, branding; broker, brokeraj; bungee jumping, bungee jumper; clubber, clubbing; coach, coaching; copyright, copyrighting; debate, debater; download, a downloada, entertainer, entertainment; freelance, freelancer; market, marketer, marketing; network, networker, networking; performer, performance.

Menționăm că termenii identificați în exemple au fost preluați întocmai din uz pentru a arăta că englezismele sunt instabile, ca formă, grafie și ca pronunție, ceea ce demonstrează faptul că adaptarea lor în limba română este un proces de durată. Este indiscutabil că majoritatea sunt percepute ca fiind cuvinte străine, ceea ce explică preferința, în scris, de a fi despărțite prin cratimă de articol, de morfemul de plural.

Odată cu tendința de feminizare a denumirilor de profesii și funcții, constatăm tot mai multe cuvinte formate prin moțiune: influencer - influenceriță (O influenceriță în vârstă de 24 de ani are peste 100.000 de urmăritori pe Instagram.), vlogger - vloggeriță (Tânăra vloggeriță din Chișinău se lansează în muzică.), instagramer - instagrameriță, tiktoker - tiktokeriță (Când nu sunt tiktokeriță sau instagrameriță, sunt studentă.), youtuber - youtuberiță (O youtuberiță din Cuba a fost arestată de polițiști în timpul unui interviu live.), blogger - bloggeriță (Bloggerița face parte din campania socială DiorLoveChain.), freelancer - freelanceriță (Jobul îți dă posibilitatea să lucrezi pe cont propriu, ca freelanceriță, sau să te angajezi într-un salon de lux.), gamer - gameriță (În prezent, există niște prejudecăți majore despre gamerițe.), hacker - hackeriță (O hackeriță de 12 ani face furori în SUA.), promoter - promoteriță (O societate comercială angajează promoterițe în hipermarketul Carrefour.), podcaster podcasteriță, performer - performeriță, manager - managerăl manageriță, developer - developeriță, user - useriță, businessman - businessmană, folkistfolkistă, fashionist - fashionistă, outsider - outsideriță, player - playeriță, mogul - moguliță, designer - designeriță, entertainer - entertaineriță, gangster - gangsteriță, graffer - grafferiță, hairstilist - hairstilistă 
În limbajul publicistic, termenii științifici deseori se determinologizează, fiind utilizați cu sensuri figurate. Totodată, majoritatea cuvintelor trec graniţele sferelor de activitate cu care au pătruns iniţial. „Este cazul unor termeni care migrează dincolo de domeniile lor de aplicaţie şi ,găsesc" calea spre limba generală" (Druță, 2017, p. 121).

Certificăm deci câteva englezisme utilizate și cu sens conotativ, fiind utile în diferite sectoare de ocupație, în contexte inedite: blockbuster (Ungaria a răpus Germania în „,blockbuster-ul” zilei - fiind vorba de un meci de handbal; de asemenea, referindu-se la un meci de tenis, avem - Blockbuster-ul Simona Halep vs. Serena Williams.), bodyguard (Bodyguarzii financiari ai oligarhului.), boss (Fii boss în gașca ta.), brand (Brandul personal este imaginea pe care ți-o formezi în mediul în care activezi. Brandul de Angajator nu se construieşte peste noapte.), coach (Rolul coach-ului este acela de a te ajuta pe tine să fii așa cum vrei să fii, oricare ar fi lucrul acela.), cool (Festival cool. Ținută cool.), deadline (Mai e puţin și vine deadline-ul Crăciunului.), fresh (Parfumuri fresh pentru femei. Parfumul păstrează hainele fresh până la 24 de ore.), handmade (Tânăra artistă handmade confecționează păpuși. Meșter handmade.), hit (Strugurii - „,hitul” toamnei la Piața Centrală. Un hit editorial. După ce a devenit un hit mondial ca e-book, trilogia a fost publicată în format de carte tipărită.), happy-end (Lecție de viață: Încrederea oarbă în oameni nu are happy-end. Moartea ca happy-end.), lider (Astăzi, shopping-ul online ocupă o poziție de lider. Kanal D, liderul de vineri seara. Lider în domeniul analizelor medicale.), live (Concurenții vor lupta în live-uri. Jurnalista a fost nevoită să întrerupă live-ul din motive de securitate.), look („Look-ul” cărții de vizită este foarte important, la fel de important ca informaţiile pe care aceasta le conține. Începutul fiecărui anotimp este o ocazie bine-venită de a o lua de la început, conferindu-i casei tale un look proaspăt.), trendy (Orașul Sibiu este considerat de Forbes printre cele mai „trendy” din Europa.), refresh (Mi-am dorit un refresh.), hot (Lidia Buble Single \& fabulous - cel mai hot pictorial.), upgrade (Răspunde la 8 întrebări și vezi dacă ai nevoie de un upgrade. Din când în când, un upgrade în casă e oportun.), battle (Nu pot să zic că mi-a plăcut battle-ul ăsta dintre antrenori.).

Un alt aspect la care ne referim în continuare e conversiunea termenilor. Unele adjective, primind însemnele gramaticale corespunzătoare, trec în substantive (all-inclusive-ul, handmade-ul, fresh-uri, low-cost-uri, must-have-ul, online-ului; un update, un must-do) sau adverbe (cântă live, citește online, visez non-stop, procesate handsfree, arată cool). Adjective care au devenit substantive: all-inclusive-ul (Cum a schimbat coronavirusul all inclusive-ul din hotelurile grecești. All-inclusive-ul şi carnavalul resuscitează litoralul. All inclusive-ul românesc); fresh-uri (Rețete de 
limonade, fresh-uri și smoothie-uri. Fresh-urile adună într-un pahar toate beneficiile fructelor utilizate); handmade-ul (Handmade-ul este pasiunea nostră. Handmade-ul este în vogă.); after-school-ul (Comitetul pentru Situații de Urgență a decis că afterschool-urile și creșele rămân deschise.); low-cost-uri (Low-cost-urile vor să facă concurență TAROM-ului pe cursele interne). Adjective care au devenit adverbe: casual (Sunt genul de om căruia îi place să se îmbrace casual.), cool (Fie că poartă skinny jeans şi trenci, fie tricou lejer şi blugi uzaţi, arată întotdeauna cool, fără efort.), live (Am insistat să mă anunțe când artistul face play-back și când cântă live.), face-to-face (Am ţinut să discutăm o astfel de ofertă face-to-face.). Verbe care au devenit substantive: to do-uri (Luna decembrie e plină de to do-uri, parcă mai multe decât în orice altă lună a anului).

Deși nu sunt atestate deocamdată în dicționare, o serie de noțiuni circulă frecvent în toate mijloacele de informare în masă în conformitate cu evoluţia situației epidemiologice la nivel mondial. Pandemia actuală, covid 19, ,a intervenit mult în viața noastră, inclusiv în vocabularul nostru, făcându-ne să însușim rapid și să utilizăm frecvent mai multe cuvinte și sensuri noi, generate anume de acestă stare pandemică” (Vulpe, 2021, p. 10).

Dacă se vor menține acești termeni în continuare sau dacă vor dispărea odată cu pandemia, vom vedea în perspectivă.

Coronavirus - Coronavirusurile infectează omul și o varietate largă de animale.

COVID-19 (abreviere de la engl. COronaVirus Infectious Disease - 2019) În prezent, nu este dovedit faptul că persoanele care s-au vindecat de COVID-19 și prezintă anticorpi sunt protejate de o a doua infecție.

SARS-CoV-2 (abreviere de la engl. Severe Acute Respiratory Syndromerelated COronaVirus 2) - Infecție cu SARS-CoV-2.

Booster (Cantitate foarte mică de vaccin care este administrată pentru a crește efectul aceleași substanțe utilizate mai devreme, cu scopul de a proteja de o boală un timp îndelungat). În contextul pandemiei, acest termen specifică a treia doză de vaccin anti-COVID-19. - Booster-ul reprezintă o protecție suplimentară împotriva coronavirusului și poate fi efectuată doar cu vaccinuri de tip ARN mesager. Din cauza mutațiilor virusului, avem nevoie de acest booster.

Panic buying - Panic buying a golit rafturile în mai multe țări.

Lockdown - Lockdown-ul a atenuat răspândirea virusului și presiunile asupra sistemului medical și a contribuit substanțial la salvarea de vieți omenești.

Spike - Anticorpii vaccinali nu se mai potrivesc cu varianta proteinei spike a tulpinilor în circulație. 
Testul Real Time PCR (abreviere de la engl. Polymerase Chain Reaction)Dacă vreți să călătoriți în alte țări s-ar putea sa aveți nevoie să prezentați un rezultat negativ pentru un test $R T-P C R$ efectuat.

O mască FFP (abreviere de la engl. „Filtering Face piece Particles) este o mască individuală de protecție respiratorie. Măștile $F F P 1$ rețin $80 \%$ dintre particule, FFP2 rețin 95\% dintre particule și FFP3 - 99\% dintre particule.

Termoscaner din engl. thermoscanner - Odată cu introducerea măsurilor anti-COVID-19, în mediul online au circulat tot felul de avertismente despre „pericolul” termometrului cu laser și a termoscanerului, care ar „marca izotopic” oamenii.

Super-spreader a dat calculul super-răspânditor (Pacient care poate infecta multe persoane prin contact ocazional scurt sau prin posibilacontaminare a mediului). - Deși este posibil, dovezile sugerează că în prezentcopiii nu sunt super-răspânditori ai virusului care provoacă boala COVID-19.

La fel, social distance, respectiv social distancing - distanță socială și distanțare socială sunt 2 sintagme înrudite care traduc formulele englezești.

În consecință, cuvintele de origine engleză care apar frecvent în paginile presei, mai ales în articole de proporții mici, sunt utilizate alternativ alături de sinonime consacrate, evitând, astfel, repetările inutile, monotonia lexicală, asigurând precizia, concizia, claritatea și eleganţa exprimării. Atunci când utilizarea englezismelor se justifică din punct de vedere terminologic și vin să acopere un gol semantic sau un sens mai precis, mai specializat, împrumuturile pot constitui o demonstraţie de înnoire şi reconstrucţie, de nuanţare semantică şi stilistică, de modernizare și îmbogățire a lexicului.

Majoritatea cuvintelor sau unitătilor frazeologice nu au un corespondent în limba română sau prezintă anumite avantaje în raport cu termenul autohton (precizie, brevilocvență, expresivitate, circulație internațională).

Pentru englezismele exemplificate în abordarea de față (preluate din mass-media, atât scrisă, cât și audiovizuală), selectate după criteriul frecvenței, au fost vizate următoarele aspecte: etimologia, definiția, prezența/absența în dicționare, necesitatea, problemele de integrare la sistemul limbii române, norma, redarea unor contexte considerate relevante.

Din perspectivă normativă, remarcăm faptul că englezismele suferă importante (sau mai puțin importante) modificări în structura lor privind aspectul fonetic, ortografic și morfologic și devin gata să-și demonstreze funcționalitatea prin valoarea semantică în îmbinări și enunțuri când sunt solicitate. De corectitudinea pronunțării, scrierii și încadrării în tiparele caracteristice ale cuvintelor din vocabularul limbii române rezultă sensul care va fi purtat în circulație: inadecvat sau în toată plenitudinea sa, cu diversitatea 
nuanțelor deja existente, dar și mereu cu tentația să-și acumuleze noi potențiale de exprimare.

În concluzie, corpusul reprezentativ de englezisme care au pătruns în limba română își caută locul adecvat în diferite domenii (știință, tehnologii, comunicații, cultură, economie, politică, sport, divertisment). Utilizarea englezismelor în contexte cât de cât relevante este încă într-o continuă încercare de a-și găsi un loc mai potrivit.

\section{Referințe bibliografice:}

1. CARUNTU-CARAMAN, Livia. Englezismele în presa periodică din Republica Moldova (aspectele funcțional, fonetic, ortografic, morfologic, semantic): teză de doctor în filologie. Chișinău, 2017.

2. CONDREA, Irina. Adaptarea cuvintelor împrumutate. În: Limba română, 2002, nr. 1-3, p. 9-12.

3. DRUȚĂ, Inga. Neologismul și „,sentimentul de neologie”. În: Norma limbii literare intre tradiţie şi inovaţie. Materialele simpozionuliui științific cu participare internaţională. Chișinău, 19 mai 2017. p. 118-124.

4. GRAUR-VASILACHE, Maria. Tendințe de internaționalizare și modernizare a terminologiilor de specialitate. În: Limba română. 2003, nr. 6-10, p. 214-228.

5. IORDAN, Iorgu, ROBU, Vladimir. Limba română contemporană. București: Ed. Didactică și Pedagogică, 1978.

6. PRUTEANU, George. AGRAMATICA MICULUI (DAR RĂULUI!) ECRAN. [online]. Disponibil: http://georgepruteanu.ro/6atitudini/2008.02.07-limba.htm [citat 18.10.2021].

7. STOICHIȚOIU-ICHIM, Adriana. Observații privind influența engleză în limbajul publicistic actual (I). În: Limbă și Literatură. București, 1996, Vol. II., p. 37-46.

8. STOICHIȚOIU-ICHIM, Adriana. Influența engleză în terminologia politică a românei actuale. În: Aspecte ale dinamicii limbii române actuale. Actele colocviului Catedrei de Limba Română, 27-28 noiembrie 2002, II. Editura Universității din București, 2003. [online]. Disponibil: https://www.diacronia.ro/en/indexing/details/V3919/pdf [citat 14.10.2021].

9. STOICHIȚOIU-ICHIM, Adriana. Vocabularul limbii române actuale. Dinamicăl Influențel Creativitate. București: BIC ALL, 2007.

10, VULPE, Ana. Achiziții lexicale „ultrarecente” pentru vocabularul limbii române. În Limbă/ Literatură/ Folclor. Nr. 1, 2021, p. 7-19.

Notă: Articolul a fost realizat în cadrul proiectului de cercetare 20.80009.1606.01 Valorificarea științifică a patrimoniului lingvistic național în contextul integrării europene, Institutul de Filologie Română „B.P.-Hasdeu” al MEC. 